MILAN KOLJANIN, naučni saradnik

Institut za savremenu istoriju

UDK 94(497.1)"1941"

Beograd, Trg Nikole Pašića 11

327(497.1:73)"1941"

\title{
POGLED IZ VAŠINGTONA NA MARTOVSKE DOGAĐAJE 1941. U BEOGRADU*
}

\begin{abstract}
APSTRAKT: Sa otpočinjanjem Drugog svetskog rata, Jugoslavija se našla u veoma teškoj situaciji. Knez Pavle je nastojao da dobije podršku Sjedinjenih Američkih Država zbog čega je krajem 1939. uputio dr Davida Albalu u specijalnu misiju u Vašington. Diplomatski izveštaji D. Albale i njegov dnevnik su dragocen izvor za stav poslanika Fotića i drugih članova poslanstva prema događajima u zemlji koji su kulminirali marta 1941, kao i za reagovanje američke javnosti na te događaje.
\end{abstract}

Ključne reči: Knez Pavle, dr David Albala, specijalna misija u Vašingtonu, politika SAD, poslanik Konstantin Fotić, vojni puč, američka javnost

Dramatični događaji u Jugoslaviji i na Balkanu tokom marta i aprila 1941. dobijali su na ubrzanju. Američka politika i javnost postali su izuzetno zainteresovani za te događaje što je kulminiralo u vreme vojnog puča 27. marta i Aprilskog rata $1941 .{ }^{1} \mathrm{O}$ događanjima u jugoslovenskom poslanstvu u Vašingtonu i reagovanju američke javnosti postoji jedan do skoro nepoznat istorijski izvor - Dnevnik dr Davida Albale, specijalnog delegata pri Jugoslovenskom kraljevskom poslanstvu u Vašingtonu. On se od kraja 1939. nalazio u svojoj drugoj misiji u SAD, gde ga je uputio knez namesnik Pavle sa namerom da ojača veze sa tom zemljom. Pokušaj jačanja odnosa sa SAD, a od proleća 1940. i uspostavljanje privrednih i diplomatskih veza sa Sovjetskim Savezom, govorili su o sve težem spoljnopolitičkom

${ }^{*}$ Rad je deo projekta Srpsko društvo u jugoslovenskoj državi u 20. veku: između demokratije i diktature (broj 177016), koji finansira Ministarstvo prosvete i nauke Republike Srbije.

${ }^{1}$ Vojislav G. Pavlović, Od monarhije do republike. SAD i Jugoslavija (1941-1945), Beograd-Banja Luka 1998, 9-13; Konstantin Fotić, Rat koji smo izgubili. Tragedija Jugoslavije i pogreške Zapada. Memoari, Beograd 1995, 32-56. Videti i: Jakob Hoptner, Jugoslavija u krizi 1934-1941, Rijeka 1971, 209-243. 
položaju Jugoslavije i njenim naporima da se izvuče iz diplomatske i vojne izolacije. $^{2}$

Knez Pavle nije slučajno izabrao dr Davida Albalu za misiju koja je tokom tri meseca ostala u punoj diskreciji čak i za njegove najbliže saradnike i prijatelje. ${ }^{3}$ David Albala je bio jedan od najistaknutijih jevrejskih javnih delatnika u Srbiji, a zatim i u jugoslovenskoj državi. Njegova prva misija u SAD bila je tokom Prvog svetskog rata po nalogu predsednika vlade Nikole Pašića. On je veoma uspešno delovao na pridobijanju američke javnosti za srpske ratne ciljeve, kao i na popularisanju cionističke ideje.

Posle početnih nesporazuma između Davida Albale i poslanika u Vašingtonu Konstantina Fotića, njihovi odnosi su uglavnom normalizovani. Poslanik ga je često pozivao na razgovore, obaveštavao o najosetljivijim političkim pitanjima i očekivao njegov sud.

Poslednji, dvanaesti izveštaj o političkim prilikama i o svom radu u SAD, Albala je uputio ministru inostranih poslova Aleksandru Cincar-Markoviću i knezu Pavlu 8. februara 1941. Njegovo praćenje javnog mnjenja i stavova uticajnih ljudi dalo mu je povod da iznese procene koje su se razlikovale od ranijih: „Politički horizont američkih vodećih krugova s pogledom na međunarodnu situaciju, za poslednja dva meseca toliko se proširio i njihova politička svest toliko je sazrela, da se američki političari danas ne bave poglavito držanjem pojedinih velikih sila kao glavnim faktorima koji utiču na današnji ratni sukob, što su do sada činili, no su stali obraćati pažnju i na stav pojedinih manjih država došavši do saznanja, da je neobično važno, da svaka od njih pripomogne svim svojim silama da se osigura krajnja pobeda demokratije." Albala je posebno istakao princip „da će pobedonosne demokratije na budućoj svetskoj konferenciji mira odrediti položaj i utvrditi prava pojedinim narodima prema ulozi koju je dotičan narod igrao u toku rata./.../ Države, koje će se bez borbe predati, biće tretirane kao elementi koji su izgubili i svoju vitalnost i svoju sposobnost da sobom samostalno upravljaju, i prema tome biće podređene drugim narodima, koji su pokazali više otporne snage, a ujedno i da su dorasli zadatku da umeju da upravljaju sami svojom sudbinom"."

${ }^{2}$ Od dobijanja uputstava za svoju misiju od kneza Pavla 16. novembra 1939. do 18. septembra 1941. D. Albala je vodio dnevnik koji je pohranjen u Jevrejskom istorijskom muzeju u Beogradu (dalje: JIM), Zaostavština dr Davida Albale (dalje: ZDA). Zaostavština se sastoji od fascikle sa ličnim dokumentima i 7 svezaka dnevnika. Njemu su priloženi brojni isečci iz američkih novina, koji još više uvećavaju izvornu vrednost dnevnika.

3 JIM, ZDA, pismo dr Davida Albale Davidu A. Alkalaju, Vašington, 29. mart 1940. Ovde je Albala objasnio razloge svog iznenadnog odlaska i zamolio za kratak izveštaj o radu Opštine. Vrhovni rabin dr Isak Alkalaj mesec dana ranije, 29. februara 1940, javio se pismom D. Albali; JIM, ZDA.

${ }^{4}$ Arhiv Jugoslavije, fond Kraljevsko poslanstvo u Vašingtonu (oznaka fonda: 371), 190, dosije dr Davida Albale, Dr. David Albala, specijalni delegat pri Kraljevskom Jugoslovenskom poslanstvu u Vašingtonu, Izveštaj broj 12, Vašington, 8. februar 1941. 
Albalin izveštaj nije izražavao samo mišljenje američke javnosti i političkih krugova, koji su nastojali da Jugoslaviju uključe u planirani britanski antinemački blok na Balkanu i spreče njeno pristupanje Trojnom paktu. ${ }^{5}$ Kao veliki demokrata i protivnik totalitarnih sila, posebno nacističke Nemačke, on je sa velikom zebnjom posmatrao približavanje Jugoslavije Osovini sluteći propast i za zemlju i za jevrejski narod.

Izveštaj od 8. februara 1941. treba shvatiti u prvom redu kao njegovo upozorenje da država ne sme da se preda bez borbe i da će od toga zavisiti njen posleratni položaj, pa i sam opstanak. Tokom istog meseca njegove crne slutnje samo su se pojačavale pa je 25. februara zabeležio sledeće: „kad pomislim da će se naša zemlja predati Nemcima bez borbe, a svi znaci govore za to, osim ako se ne desi neko čudo, i kad pomislim da će uskoro Nemci postati neograničenim gospodarima naše zemlje, dođe mi da svisnem od bola. Evo, do čega su nas Englezi i Francuzi doveli, a donekle i Amerikanci. Naši će robovati i skapavati, a mi ovde postaćemo izbeglice, možda nepovratno. Sve, ako i Englezi uz pomoć Amerikanaca i pobede, a to će ići ne samo teško, no će i dugo trajati-nema izgleda da će Jugoslavija ikad više u dosadašnjem obliku uskrsnuti. Prema našem učešću u borbi za slobodu, dodeliće nam se nagrada posle rata. Naša danas prema Hitleru ponizna glava doneće nam ne samo prezir pred licem današnjeg sveta i licem budućih generacija, no će nam potpuno uništiti šanse da po završenom ratu povratimo svoju nezavisnost." ${ }^{6}$ Poslanik Fotić je 17. februara upoznao Albalu sa političkom situacijom i sadržajem razgovora Cvetkovića i Cincar-Markovića sa Hitlerom. U zamenu za pristupanje Osovini i ustupanje dela Južne Srbije (Makedonije) Bugarskoj, Hitler je Jugoslaviji nudio Solun ${ }^{7}$ i deo severne Albanije. Poslanik je bio pesimista u pogledu daljeg razvoja situacije u zemlji i na Balkanu. Predviđao je da će Nemci preko Bugarske zauzeti Solun, primorati Grke na mir, a da će nas vrlo verovatno razoružati. U slučaju nemačkog ulaska u zemlju bio je uveren da će dinastija napustiti zemlju, a dalmatinska obala biti ustupljena Italiji. Albala je zamolio poslanika da obavesti kneza „da sam i ja i moji prijatelji za to, da naši ne popuste". Nameravao je da i sam pošalje telegram sa takvom porukom, a na kraju zapisa u dnevniku se upitao: „Da li će naša vojska i naš narod primiti tako ponižavajuće rešenje ili je situacija zaista bezizlazna?" Iako nije odobravao politički pravac kojim se kretala zemlja, Albala je nalazio opravdanje za postupke kneza namesnika: „Kod nas postoji velika polit./ička/ pometenost. Knez Pavle, - siromah, on nosi svu odgovornost(...). ${ }^{8}$

\footnotetext{
${ }^{5} \mathrm{~V}$. Pavlović, Od monarhije do republike, 9.

${ }^{6}$ JIM, ZDA, Moj dnevnik, sv. 5, str. 25, Utorak, 25. februar (1941).

${ }^{7}$ Istovremeno, Hitler je velikodušno nudio Solun i Bugarskoj o čemu je Jugoslavija obaveštena januara 1941; K. Fotić, Rat koji smo izgubili. Memoari, 37.

${ }^{8}$ JIM, ZDA, Moj dnevnik, sv. 5, str. 21, Petak, 21. februar (1941). U nedelju, 23. februara 1941, posle šest dana odlaganja, poslao je sledeći telegram: „Molim hitno saopštite gore da nipošto ne popuste, hvala"; isto, str. 23.
} 
Vesti iz zemlje bile su oskudne, ali je stanje na Balkanu krajem februara 1941. i početkom marta 1941. bilo, očigledno, kritično. U američkoj javnosti od Jugoslavije kao da se više ništa nije očekivalo: „U ovd./ašnjoj/ štampi našu zemlju skoro potpuno ignorišu. O svima ostalim balkanskim zemljama se svakog dana opširno govori. Ceneći da smo već rešeni da primimo nem.(ačku) dominaciju, simpatije za našu zemlju sve su manje." ${ }^{\text {9 }}$

Nadmetanje Nemačke i Velike Britanije oko Jugoslavije Albala je ovako komentarisao: „Bojim se da se is nama ne dogodi ono: 'od silne ljubavi rastrgli zeca"”. U poslanstvu Albala je mogao da čuje razna mišljenja: „Sarić mi jutros u posl./anstvu/ kaže, da smatra da se naša zemlja neće dati pokoriti bez otpora. A Sekulić mi naknadno citira Sarićeve reči da bi naša vojska ubila Kneza Pavla, ako bi ovaj potpisao trojni pakt." Albala je u poslanstvu prema sebi opet osetio zid nepoverenja za šta je krivio Fotića: „Samo sam im dobar da im dajem lekarske savete. Radi toga sam iz Beogr./ada/ upućen ovamo."10

Ipak, poslanik je i dalje sa Albalom vodio poverljive razgovore: 6 . marta 1941. Fotić ga je izvestio o pregovorima kneza Pavla sa Ribentropom (uz prisustvo Ćana) na Brdu kod Kranja, i o planiranoj kneževoj poseti Hitleru. Obojica su se složila da bi pristup zemlje Trojnom paktu i ulazak Nemaca i Italijana značio konačan raspad Jugoslavije. Fotić je obavestio Albalu i o dva svoja telegrama upućena u Beograd sa molbom da se ne popusti nemačkim zahtevima i dodao: „'Da Vas obavestim. Mojom inicijativom Rozvelt je već u dva maha preko amer.(ičkog) posl./anstva/ intervenisao kod naše vlade.' Ja ga molim da pod mojim potpisom izvesti Min./istra/ i Kneza da sam i ja protiv pristupanja paktu." Poslanik to nije prihvatio nego mu je savetovao da pošalje javno telegram direktno knezu. U diskreciji, poslanik je poverio Albali da će se u slučaju da Nemci uđu u zemlju povući sa položaja što je u dva maha nagovestio i u Stejt departmentu. Rastali su se veoma deprimirani. ${ }^{11}$

Pisanje američke štampe navodilo je Albalu na uznemirujuće zaključke: „Ovd./ašnja/ štampa demantuje sinoćne nem./ačke/ vesti da je Roz./velt/ 14. febr./uara/ preko Fotića vršio pritisak na našu državu da /ne/ priđe osovini. Međutim, to je istina, jer mi je to i Fotić pričao odmah po polovini febr./uara/ pominjući Welles-a, ali ne i Roz./velta/ Kako su to Nemci doznali?

${ }^{9}$ Isto, str. 25, Utorak, 25. februar (1941); isto, str. 31, Ponedeljak, 3. mart (1941). Tog dana, prema Albalinoj belešci, Fotić i Ribarž su se veoma utučeni vratili iz Stejt departmenta.

${ }^{10}$ Isto, str. 33, Sreda, 5. mart (1941).

${ }^{11}$ Isto, str. 34, Četvrtak, 6. mart (1941); videti i: K. Fotić, Rat koji smo izgubili. Memoari, 41-42. Fotić je zabeležio i da je planirao da, u slučaju potpisivanja Trojnog pakta, podnese ostavku i osnuje Komitet za slobodnu Jugoslaviju, ali mu je Stejt department savetovao uzdržanost. „U ovom stavu ohrabrivala me je i prijateljska podrška članova poslanstva, koji su, skoro bez izuzetka, delili moje mišljenje i sledili moj primer." K. Fotić, n. d., 58. 
Koji su to špijuni?" Po Albalinoj oceni knez Pavle i dalje je pokušavao da održi neutralnost, ali bilo je jasno da to nije moguće i da zemlji predstoje teški dani: „Zar može danas ma koja, a tek jedna mala država, koja leži na sred puta kojim Nem./ačka/ nadire, da ostane beskonačno „neutralna“. Ja se bojim, da će sa ulaskom nem./ačke/ vojske u našu zemlju, otpočeti kod nas građanski rat, a to će biti gore no rat, a ujedno biće i kraj naše nezavisnosti." Za osmi mart 1941. bile su, ipak, vezane i velike nade: u američkom Senatu izglasan je Zakon o zajmu i najmu (Land-Lease Act) i Albala je očekivao da će slediti brza američka pomoć Jugoslaviji. ${ }^{12}$

Tokom dugog razgovora 9. marta 1941. poslanik je, uz ostalo, upoznao Albalu sa velikom neprilikom u kojoj se našao zbog američkog demantija u štampi Ruzveltove intervencije u Beogradu. Za sadržaj njegovog telegrama upućenog u zemlju, tvrdio je poslanik, Nemci su mogli da saznaju jedino preko svojih špijuna u našem ministarstvu inostranih poslova. „Doveli su i mene i Rozvelta u nezgodan položaj. State Dep./artment/ mi prebacuje kako mi ne umemo da čuvamo tajnu. Pa to je strašno. Juče sam hteo da idem u State Dep./artment/, ali mi rekoše da ne dolazim da moj dolazak ne bi pao štampi u oči, već će mi uputiti jednog svog visokog činovnika. I zaista, on je juče po podne bio kod mene.'/.../ Dobio sam utisak, da su Rozveltovu intervenciju ispričali naši najviši činovnici u min./istarstvu/ Sp./oljnih/ Poslova kao nemački špijuni. Zaista strašno. Još je i to F./otić/ dodao: 'Jedino dobro iz cele te Rozveltove intervencije jeste to, što je i naša javnost u Jug./oslaviji/ doznala da R./uzvelt/ stoji iza naše zemlje." I I pored neslaganja sa kneževom politikom, Albala je smatrao da je on radio u najvišem interesu zemlje i da joj je produžio život za nekoliko nedelja. ${ }^{13}$

Mada u svojoj analizi nezavidne situacije u kojoj se našla zemlja Albala nije imao mnogo iluzija, on je ostavljao i tračak nade: „Najverovatnija su rešenja, prema tome, ili sramno ropstvo, bez borbe, ili ropstvo posle herojske borbe." Smatrao je da postoji i mala mogućnost uspešnog otpora u Srbiji ili Južnoj Srbiji uz pomoć Turske, Grčke i Velike Britanije, ali pod uslovom da bude održana veza sa Grčkom. Ako bi se desilo da se prekine ta veza, „onda je naš vojni, a zatim i politički poraz potpun, i naša je nezavisnost nepovratno izgubljena./.../ Još ne gubim nadu da će naši odupreti u poslednjem trenutku. Inače pretstoji sramno i očajno ropstvo."14

U Vašington su stizale i vesti o sve većem neraspoloženju u zemlji prema vladi i njenoj nameri da potpiše pakt. Očekivao se i neki iznenadan prevrat u kome će glavnu ulogu imati vojska. „Ali zemlja u svojoj ogromnoj većini je protiv toga što se vidi po naročitom raspoloženju. I mobilisani i nemo-

${ }^{12}$ JIM, ZDA, Moj dnevnik, sv. 5, str. 36, Subota, 8. mart (1941); Robert E. Sherwood, Ratne tajne Bijele kuće, Zagreb 1952, sv. 1, 343-344.

${ }_{13}^{13}$ Isto, str. 37, Nedelja, 9. mart (1941); videti i: K. Fotić, Rat koji smo izgubili, 39-40.

${ }^{14}$ Isto, str. 38, Ponedeljak, 10. mart (1941). 
bilisani piju, pevaju ratne pesme i lumpuju. Drže se vatreni govori na svima stranama, pa i oficiri u uniformi. Vladika Nikolaj raspaljuje masu na viteška dela. Narodna odbrana i četnici pod Kostom Pećancem upisuju nove dobrovoljce i zaklinju se da će braniti zemlju." Da li vlada pokušava da dobije na vremenu očekujući oružje od Britanije i Amerike i iskrcavanje jačih engleskih snaga, pitao se Albala. Sigurno je da Nemci neće dati da se odluka odlaže u nedogled. „S druge strane, ako naši ipak potpišu pakt, ja verujem da će vojska uzeti stvar u svoje ruke i povesti zemlju putem snažne samoodbrane./.../ Narod je razjaren, jer ga ne samo spoljni događaji dovode do ludila, no i neizvesnost i nepoznavanje unutrašnjih političkih činjenica. Kada očajanje zahvati masu, ona je u stanju da počini mnoga luda dela. Ipak verujem u zdrav instinkt Kneza Pavla i javnoga mišljenja, naročito u Srbiji i u Slovenačkoj. “15

Albalu je posebno ohrabrivao promenjen stav SAD posle usvajanja Zakona o zajmu i najmu kojem su odmah usledile velike američke isporuke oružja Britaniji. To je ohrabrilo Grčku i Jugoslaviju koje su takođe očekivale američku pomoć. Međutim, Albala je bio svestan skoro bezizglednog položaja zemlje: „strategiski skoro sasvim opkoljeni, slabo naoružani, lišeni moćnih saveznika u neposrednom susedstvu i izloženi nasrtajima najjače svetske vojne sile. Nimalo se ne podajem nadama, da nećemo biti i mi pregaženi, isto i Poljaci, ali čuda se uvek događaju, pa mogu i sada."16

Fotić je i dalje obaveštavao Albalu o stavovima vlade i svojim kontaktima sa američkim zvaničnicima. Ohrabrivale su vesti o iskrcavanju britanskih trupa u Grčkoj i, kako se Albali činilo, o čvrstom odbijanju vlade da potpiše pakt. U nedelju, 16. marta 1941. zabeležio je nepotvrđenu vest sa radija da je predsednik Ruzvelt primio poslanika Fotića u specijalnu audijenciju i obećao hitnu pomoć Jugoslaviji, ako se odupre nemačkoj agresiji. Ispostavilo se da ova vest nije bila tačna. Američko javno mišljenje sada je pridavalo veliki značaj i usmeravalo pažnju na buduće korake Jugoslavije. Štaviše, velika američka štampa počela je da piše o njoj sa iznenađujuće naraslim simpatijama. Stalno su stizale vesti da se Jugoslavija neprekidno približava Velikoj Britaniji i njenim saveznicima Grčkoj i Turskoj, a dopisnici su javljali o spremnosti celokupnog stanovništva da se bori i umre za svoju zemlju. ${ }^{17}$

Dok su 20. marta 1941. kolale različite glasine o stavu jugoslovenske vlade, sutradan je potvrđeno da je na sednici vlade doneta odluka o potpisivanju pakta o nenapadanju sa Nemačkom. Rezultati izjašnjavanja na

${ }^{15}$ Isto, str. 39, Utorak, 11. mart (1941).
${ }^{16}$ Isto, str. 40, Sreda, 12. mart (1941); isto, str. 41, Četvrtak, 13. mart (1941). Od petka, 14. marta do nedelje, 22. marta, kao i u utorak 24. marta 1941, Albala je vodio dnevnik na engleskom jeziku.

${ }^{17}$ Isto, str. 44, Nedelja, 16. mart (1941); isto, Ponedeljak, 17. mart (1941). 
sednici vlade bili su za Albalu indikativni, jer su svi hrvatski ministri bili za potpisivanje pakta. Raspoloženje među Srbima bilo je odlučno protiv, što je sve moglo da odvede zemlju u građanski rat. Ova vest je izazvala opštu potištenost u poslanstvu. Albala je odlučio da, bez obzira na posledice, u svoje ime pošalje tri telegrama: prvi knezu Pavlu u kome ga preklinje da u ovom istorijskom času "radije primi borbu no ropstvo" jer će samo ona omogućiti vaskrs državne nezavisnosti, drugi telegram predsedniku SAD F. Ruzveltu sa preklinjanjem da pomogne njegovom narodu u otporu Nemcima i treći predsedniku britanske vlade V. Čerčilu sa molbom da pomogne jugoslovenski narod u otporu nemačkom pritisku. Poslanik Fotić je posle dva dana pohvalio Albalu zbog slanja ovih telegrama. ${ }^{18}$

Kako se približavalo očekivano jugoslovensko pristupanje Trojnom paktu, vesti i glasine su sustizali jedni druge. Albala je, kao i mnogi drugi, očekivao neki dramatičan preokret u kome bi vojska imala vodeću ulogu. Postojali su jasni znaci unutrašnjeg otpora proosovinskoj vladi, a njemu se činilo da ceo svet čeka konačnu odluku vlade u Beogradu. ${ }^{19} \mathrm{U}$ nedelju, 23. marta 1941. Albala je u poslanstvu saznao da su knez Pavle i vlada rešili da, verovatno već za dva dana, potpišu pakt. I poslanik Fotić i savetnik Ribarž osuđivali su kneza i vladu zbog „mlakog i beskičmenog držanja prema Nemačkoj“. Fotić je obavestio Albalu o svojoj jučerašnjoj poseti Stejt departmentu gde je državni podsekretar Samner Vels (Sumner Welles) odbio njegovu molbu da javno podrži jugoslovenski narod i u ovom času i u budućnosti na mirovnoj konferenciji. „F./otić/ ovako tumači držanje Kneza. Knez ne želi rat, jer neće da se lično izlaže neugodnosti izbegličkog života." Albala je smatrao da poslanik treba mnogo energičnije da zatraži podršku od američke vlade. $^{20}$

Posle vesti da su 24. marta predsednik vlade Cvetković i ministar inostranih poslova Cincar-Marković otputovali u Beč na potpisivanje pakta, u poslanstvu su svi, sa izuzetkom apolitičnog Rastka Petrovića, osuđivali stav vlade. Ubrzo se pojavio i Fotić koji je od S. Velsa saznao da su Nemci postavili jugoslovenskoj vladi ultimatum da u roku od 12 časova jasno pristupi Osovini. Svi u poslanstvu očekivali su da će u narednim danima doći do neke vrste vojne pobune i obrazovanja nove vlade u Skoplju. Nikakva stvarna pomoć od saveznika, međutim, nije stizala i Albala je sa žaljenjem zaključio kako niko ne shvata veliki značaj slobodne Jugoslavije i Balkanskog poluostrva. ${ }^{21}$

${ }^{18}$ Isto, str. 48, Četvrtak, 20. mart (1941); isto, str. 49, Petak, 21. mart (1941); isto, str. 51, Nedelja, 23. mart (1941).

${ }^{19}$ Isto, str 50, Subota, 22. mart (1941).

${ }^{20}$ Isto, str. 51, Nedelja, 23. mart (1941).

${ }^{21}$ Isto, str. 52, Ponedeljak, 24. mart (1941). 
Vest da su u Beču 25. marta 1941. predstavnici Jugoslavije potpisali pakt sa Nemačkom izazvala je veliku pažnju američke javnosti o čemu je Albala, između ostalog, zabeležio: „Članci u štampi objavljeni danas pišu sa simpatijama o nama i ističu da se naša država odlično držala kada je tako dugo odolevala nemačkom pritisku /.../ Još se ističe kao naš veliki uspeh što smo uspeli da ne primimo ponižavajuće uslove po nas koje nam je Nemačka postavila, naime da propustimo ne./mačke/ trupe kroz našu zemlju./.../ Naša vlada smatra da je takvim paktom, najboljim koji se mogao dobiti od Nemaca pod ovakvim okolnostima, spašena čast našeg naroda jer je sačuvana naša politička nezavisnost i održan netaknut naš teritorijalni integritet /.../ Ipak, jedno je jasno, narodna tragedija je otpočela."

Albala je bio svestan da ni on, kao ni ostali učesnici događaja ne mogu objektivno da analizuju taj događaj o kome su mišljenja bila (i ostala) podeljena. Za jedne, bila je sačuvana državna celina za sve vreme dok traje rat, zemlja je pošteđena od rušenja, sačuvani su životi celokupnog stanovništva. Za druge, ukaljana je narodna čast, skrhani su narodno dostojanstvo i ponos, izgubljena je narodna sloboda i nezavisnost i nastupilo je sramno ropstvo. „Ko je u pravu? Teško je reći. Možda oba gledišta sadržavaju veliki deo istine u sebi. Tek će docnija istorija dati za pravo jednom ili drugom shvatanju. Međutim, svi priznaju da su oba rešenja dva zla. Pitanje je samo, koje je zlo veće."

Istog dana Albala je u poslanstvu obavestio Fotića da će sutradan otići u privatnu posetu sudiji Vrhovnog suda F. Frankfukteru i upitao ga da li treba od njega nešto da zatraži. Fotić je rekao Albali da mu prenese stav da je Jugoslavija izgubila svoju nezavisnost, ali je ne treba gurati dalje u nemačko naručje. Takav stav Fotić je istog dana izneo i britanskom ambasadoru u Vašingtonu Halifaksu. Moguća je i reakcija u narodu, istakao je Fotić, koja iz osnove može da promeni situaciju. Poslanik je detaljno izneo Albali svoju analizu situacije prema kojoj bi najgore bilo da se duhovi u zemlji smire i da zatim Nemačka zatraži demobilizaciju. Odlazak vojnika kućama značio bi brzu nemačku okupaciju. Pomenuo je zatim mogućnosti formiranja nove vlade na jugu zemlje ili postojanja dve paralelne vlade. „A što se tiče Kneza, sa njim je svršeno. On je potpuno izigrao. On više ne može da bude narodni vođ. S time treba biti načisto."

Albala je pokušao da nađe opravdanje za kneževo postupanje $u$ činjenici da Grčka nije ništa dobila od SAD ni posle tri meseca ratovanja i pored neprekidnog moljakanja. „A tek šta smo mi dobili za poslednju godinu i po dana u Amer./ici/? Ništa, nego smo zajednički obijali njihove pragove i zapomagali da nam se pomoć pošalje pre nego što bismo bili primorani da uđemo u rat. Šta su nam Amer./ikanci/, a šta su nam Englezi dali? Opet ništa." Oružja i pomoći ni od kuda. „I Rusija nas je prevarila i stalno je samo nas ćuškala u rat, a sama se izvlačila, pa i Turska je još pre 4 dana izjavila da nas neće vojnički pomoći, ako nas Nem./ačka/ napadne. Dakle bili smo napušteni od svih./.../ Nisu 
li možda i to razlozi što se Knez odlučio da sa Nemcima zaključi pakt?" Albala je naglasio Fotiću da to ne govori kao neki knežev advokat nego na osnovu objektivnih činjenica i sopstvenog iskustva u SAD. Vraćajući se na sutrašnju posetu Frankfurteru, Fotić je odobrio Albali da upotrebi svoje jasne i oštre argumente u pokušaju da se pomogne Jugoslaviji. U veoma otvorenom i iskrenom razgovoru sa Frankfurterom narednog dana, Albala je od njega dobio obećanje da će se kod Ruzvelta i ministra vojske zauzeti za što hitniju pomoć Jugoslaviji. ${ }^{22}$

O događajima povodom državnog udara od 27. marta 1941. Albala je zabeležio i sledeće: „27/III Jutros radio javlja o ostavci naših namesnika i vlade, o revoluciji, o preuzimanju vlasti od strane gen./erala/ Simovića, o stupanju na presto Kralja Petra Drugog, o bezgraničnom i ludom oduševljenju u Beogr./adu/i u celoj zemlji, o žestokim antinem./ačkim/demonstr./acijama/ u Beogr./adu/, o mogućem otkazivanju prekjuče potpisanog pakta. Ludi smo od sreće i mila $^{23}$ i Jela i ja. Poslanstvo takode. Na radiu nas hvale sve samim superlativima. Sram je sram, ali očekujemo rat. On je izgleda neizbežan. Kakav nagli preokret. Zemlja je ujedinjena./.../ Naređena je puna mobilizacija. Ceo svet je radosno naelektrisan. U poslanstvo neprestano stižu depeše s čestitkama. Fotić je poslao velike depeše Kralju i generalu Simoviću kao pretsedniku vlade." I sutradan Albala je u dnevniku dao maha izrazima svoga oduševljenja događajima u zemlji, koji su, po njemu, izazvali ogroman utisak u svetskoj javnosti. „Podigli smo iz mrtvila moral demokratskih naroda i ulili svežu krv u već apatične nacije. Lupili smo Hitlera posred lica /.../ Naneli smo diplom./atski/ i psihol./oški/ poraz najvećoj vojničkoj sili sveta, i to ko? Mali David-džinu Golijatu. Svet je zabezeknut, i svi se pitaju ko je taj narod, ko je ta zemlja-Jugoslavija? Svi govore o 'Turning point of the war,' ${ }^{24}$ a mi se pitamo, je li to java ili san? Silan je naš narod. Beskrajno hrabri su naši Srbi naši Srbi!" Ushićen preokretom u zemlji, Albala je u svojstvu specijalnog delegata jugoslovenske vlade u Vašingtonu poslao četiri pozdravna telegrama u Beograd: Njegovom veličanstvu kralju Petru Drugom, predsedniku Kraljevske vlade generalu Dušanu Simoviću, ministru spoljnih poslova Momčilu Ninčiću i Savezu jevrejskih opština. ${ }^{25}$

${ }^{22}$ Isto, str. 53, Utorak, 25. Mart (1941); isto, str. 54, Sreda, 26. mart (1941).
${ }^{23}$ D. Albala tako u dnevniku naziva svoju suprugu Paulinu Lebl Albala.
24 "Prekretnica rata“ (engl.).
${ }^{25}$ "JIM, ZDA, Moj dnevnik, sv. 5, str. 55, Četvrtak, 27. mart (1941); isto, str. 56, Petak, 28. mart (1941); o knezu Pavlu Albala je tog dana zabeležio: „Za Kneza su javili da je prebegao u Grčku, zatim da je ubijen, pa da je uhapšen. Neka samo živi. Mnogi, pa i ja, znamo da je voleo zemlju, da je bio liberalan tip - lično (iako Njegova vladavina na žalost, nije bila liberalna, $i$ da je po duši bio veliki Englez i veliki Francuz)." Tekst telegrama Savezu jevrejskih opština glasi: „U sudbonosnom istoriskom času ubeđen sam da će jugoslovenski Jevreji i nadalje požrtvovano vršiti dužnost prema našoj miloj Otadžbini." Videti i: Branko Petranović, Nikola Žutić, 27. mart 1941. Tematska zbirka dokumenata, Beograd 1990; K. Fotić, Rat koji smo izgubili, 44-75. 
U novim okolnostima D. Albala je dobio i nove zadatke od poslanika. Fotić je sve činio da se ogromno interesovanje za Jugoslaviju iskoristi za što hitnije upućivanje pomoći u zemlju i da se njen glas što više čuje u SAD i svetu. Prilikom razgovora 2. aprila 1941. poslanik je preneo Albali sadržaj svog jučerašnjeg razgovora sa predsednikom vlade Simovićem. Vrlo optimistički raspoložen, Simović je rekao Fotiću: „'Ne brinite o nama. Mi smo spremni. Ako nas napadnu, branićemo se. Vi tamo u Vašingtonu budite čvrsti. A Vi, g. F./otiću/, šta god radite za nas - dobro je i mi smo zadovoljni.'“ Fotić je obavestio Albalu da je prethodnog dana bio u Njujorku radi osnivanja velikog jugoslovensko-američkog odbora (lige) na čemu su angažovani Luj Adamić (Albala je tako pisao njegovo prezime) i mnogi drugi naši ljudi, a zatim se sa njim posavetovao o rukovodstvu odbora. Fotić mu je izneo i da se osnivaju naši specijalni odbori za pomoć i propagandu i da će Svetislav Petrović biti angažovan kao stalni spiker radio stanice u Bostonu. Sredinom aprila 1941. Fotić se u Njujorku dogovorio sa nekolicinom istaknutih američkih javnih radnika o učešću u američkojugoslovenskoj ligi. ${ }^{26}$

Albala je predložio da u američko-jugoslovenski odbor uđe i u jedan Jevrejin sa čim se Fotić složio i predložio da to bude ugledni američki bankar Bernard Baruh (Baruch).„F/otić/: Vi ćete u moje ime ići k njemu i zamoliti ga da se toga primi. Uopšte Vi ćete održavati vezu sa cij./onističkom/ org./anizacijom/'/.../ Ja mu kažem da su se iz cij./onističke/ org./anizacije/ raspitivali kod mene da li bi F./otić/ primio Vajcmana u posetu. F./otić/ prihvaća i ovlašćuje me da to aranžiram. Još mi govori kako će mi docnije dati druge spec./ijalne/ dužnosti. Ja ga obaveštavam da mila piše članke o našoj zemlji za amer./ičku/ štampu. Govori mi da će nam Roz./velt/ poslati sad odmah, još pre nego što zaratimo oružje iz amer./ičkih/ magacina." Albala je nagovarao poslanika da traži i novac za izdržavanje vojske i audijenciju kod Ruzvelta, a ovaj mu je odgovorio da je to već planirao. Istog dana Albala je od predstavnika cionističke organizacije dobio obaveštenje da Vajcman stiže u petak 4. aprila i da bi želeo da poseti Fotića. „Interesantno je da i Vajc./man/ i ja imamo iste ideje, jer ja sam o tome sa Fot./ićem/ već već danas u podne govorio. Nešto se cijonisti mnogo o meni i o mome radu interesuju." Vesti o punoj mobilizaciji značile su da će Jugoslavija biti napadnuta. „Pišu nam da je i „Židov" zabranjen. Sve crnje i crnje. ${ }^{27}$

${ }^{26}$ JIM, ZDA, Moj dnevnik, sv. 5, str. 61, Sreda, 2. april (1941); isto, str. 72, Utorak, 15. april (1941), isto, str. 74, Četvrtak, 17. april (1941). Januara 1941. poslanik je uspeo da se na radio-stanici WRUL u Bostonu organizuje program na srpskom jeziku, koji je emitovan tri puta nedeljno; K. Fotić, Rat koji smo izgubili. Memoari, 34-35.

${ }^{27}$ JIM, ZDA, Moj dnevnik, sv. 5, str. 61, Sreda, 2. april (1941). Zagrebački nedeljnik Židov je bio glavni cionistički list u Jugoslaviji. O antijevrejskoj atmosferi u Zagrebu dva dana pred rat Albala je našao vesti u američkim jevrejskim biltenima 21. aprila 1941. 
Svi znaci govorili su Albali da će Jugoslavija ubrzo biti napadnuta. „U poslanstvu je sve veća nervoza. Dolaze mnogi naši iseljenici i raspituju se o političkoj situaciji naše zemlje. I mene lično na telefonu moji poznanici pitaju kako će /se/ dalje događaji razvijati." Američka štampa je "kovala u zvezde" Jugoslaviju, a Albala je bio ispunjen ponosom zbog velikog utiska koji je 27. mart proizveo u svetu: „Naša revolucija, ma koliko značajna po našu zemlju bila, izazvala je u čitavom svetu jednu još snažniju revoluciju, i to revoluciju duhova. Ona je ustalasala sve narode, i pokorene i neutralne, i zaraćene./.../ Naši u Jugoslaviji i ne slute koliko su svojim junačkim držanjem pokrenuli uspavane demokratske narode da i oni pođu tim putem. “28

Predsednik SAD Ruzvelt je vrlo predusretljivo primio jugoslovenskog poslanika 3. (ili 4) aprila 1941. i, prema Fotiću i Albali, rekao sledeće: "Uzmite sve što vam treba iz naših magacina' rekao mu je 'sve vam stoji na raspoloženju. Tovarite odmah i pošljite. Dobićete pored toga i novaca u gotovu. Divim se bezgraničnoj hrabrosti vašeg naroda, koji je rešen da pod najgorim uslovima za sebe prihvati neravnu borbu sa Nemcima. Pomagaćemo u svakom pogledu svima sredstvima koja imamo." Prema Zakonu o zajmu i najmu Jugoslavija je trebalo besplatno da dobije svu pomoć i Ruzvelt je rekao Fotiću da se već sutradan američkom ministarstvu finansija dostave spiskovi potrebnog ratnog i sanitetskog materijala. Poslanik je odmah pozvao Albalu u poslanstvo gde je on bez ikakvih priprema vojnom izaslaniku Mirku Burji izdiktirao potrebne količine sanitetskog materijala za jugoslovensku vojsku. Sutradan ujutro Albala je doneo u poslanstvo dopunu spiska, a zatim su Fotić i Burja odneli spiskove u ministarstvo. Kasnije je Fotić saopštio Albali da je sve što je bilo na spisku u ministarstvu umnogostručio. Ovaj materijal trebalo je prebaciti u zemlju jugoslovenskim trgovačkim brodovima. ${ }^{29}$ Posle tri dana Albala je sastavio i treći spisak potrebnih lekova.

Vest o potpisivanju sovjetsko-jugoslovenskog pakta u Moskvi koja je stigla 5. aprila 1941. uveče nije obradovala Albalu jer je smatrao da, u strahu od Nemaca, Rusi podstiču druge da ratuju, a sami ostaju van sukoba. Iste večeri stigla je i vest o Hitlerovoj proklamaciji vojsci i Ribentropovom objašnjenju. „Vest me je presekla jer ja znam šta je rat. Dakle, gorka čaša nije ni nas mimoišla./.../ Slušali smo besprekidno radio. Ja sam legao tek u tri pred

${ }^{28}$ Isto, str. 62, Četvrtak, 3. april (1941).

${ }^{29}$ Isto, str. 63, Petak, 4. april (1941); isto, str. 64, Subota, 5. april (1941). Prema Fotićevim memoarima, Ruzvelt ga je primio 3. aprila, a spiskove vojnog i sanitetskog materijala pripremali su jugoslovenski vojni ataše Mirko Burja, njegov pomoćnik i pomoćnici Harija Hopkinsa, administratora Zakona o zajmu i najmu. Hopkins je već imao listu vojnog materijala koju je jugoslovenski Generalštab dostavio američkom vojnom atašeu u Beogradu, ali bez sanitetskog materijala. - K. Fotić, Rat koji smo izgubili. Memoari, 66-69. Ministar spoljnih poslova M. Ninčić uputio je 6. aprila 1941. u ime Ministarstva vojske i mornarice poslanstvu u Vašingtonu spisak potrebnog naoružanja i ratnog materijala (aviona, tenkova, topova i drugog), ali bez sanitetskog materijala. - AJ, 371-210, Str. Pov. br. 885. 
zoru. Pojedinosti nema. Ceo je svet uzbuđen. Ministri amer./ički/ već daju izjave. Nova faza rata je otpočela. Hoćemo li izdržati ili ćemo i mi podleći kao toliki narodi do sada? Hitler nikome nikad ništa ne oprašta, ali verujem da će se naši k'o lavovi boriti. Hoće li nam kogod priskočiti u pomoć? Hoće li se svet najzad probuditi." 30

Milan Koljanin

\section{THE EVENTS OF MARCH 1941 IN BELGRADE A LOOK FROM THE WASHINGTON}

\section{Summary}

Dr David Albala, the special envoy with the Royal Yugoslav Legacy in Washington, was a notable Jew and Zionist from Belgrade. He lefted valuable accounts in his diary on effect that the Coup d' Etat in Belgrade on 27th March 1941 have in Yugoslav diplomatic circles and public in the United States. Those notes showed that the US policy was much more interested in the Yugoslavian affairs than it was estimated before, and especially regarding to the Yugoslavia's intention to join the Tripatrite Pact. But the Albala writings, showed that the effective political support from the American side to the Yugoslavia lacked, and that the support was mainly verbal. There was no further steps to stronghold this support. Albala, himself, was aware of the difficult situation that Kingsom of Yugoslavia was, and that the War was inevitable.

\footnotetext{
${ }^{30}$ JIM, ZDA, Moj dnevnik, str. 64, Subota, 5. april (1941).
} 